Marta Puxan-Oliva

\title{
The challenges of wild spaces to world literary cosmopolitanism
}

The imagination of the world and the planet have experienced a renewed interest in several critical discourses in the past three decades. However, their possibilities, limitations, and intersections are still hard to apprehend. The present volume and its precedent, Re-mapping World Literature: Writing, Book Markets and Epistemologies between Latin America and the Global South (Müller/Locane/Loy 2018), contribute to revisiting the critical intersections between world literature and other discourses such as decolonial theory, cosmopolitanism, or extractivism. This essay joins these efforts by examining a confluence of global discourses of new cosmopolitanisms, ecocriticism and world literature, guided by Joan Benesiu's Gegants de gel ('Ice Giants') (2015) and Gabi Martínez's Sudd (2007). By observing the novelistic setting of a cosmopolitan group of characters in spaces that are imagined as wild, I claim that the challenging intersection of global discourses interrogates the cosmopolitan aspirations in world literature. The novels I discuss are interested in the global both in its ethico-political and its biosocial dimensions, which center the new cosmopolitanism and the ecocritical discourses respectively. The apparently perfect integration of the cosmopolitan and the ecocritical approaches to address the global, however, proves so deeply problematic that it can help us rethink the novel - one relevant focus of interest in world literature - as a space of critical problematization of global discourses rather than of conciliation.

\section{New cosmopolitanisms and ecocriticism as global discourses}

New cosmopolitanism and ecocriticism are discourses of the global. The varied critical forms into which cosmopolitanism has been recuperated at the turn of the twenty-first century share the inquiry into the political and ethical relationship of individuals and institutions on a global scale, and an ethical project based on the recognition of a shared humanity from the point of view of what Walter Mignolo calls a "planetary conviviality" (Mignolo 2000: 721). For Pheng Cheah, any theory of cosmopolitanism addresses in one way or another the possibilities of "mutual

Ә Open Access. (C) 2019 Marta Puxan-Oliva, published by De Gruyter. (c) BY-NC-ND This work is licensed under a Creative Commons Attribution-NonCommercial-NoDerivatives 4.0 License.

https://doi.org/10.1515/9783110641134-013 
feedback with a global political consciousness that voices the universal interests of humanity and tries to maximize human freedom" (Cheah 2006: 486). In their diverse formulations, ranging from Martha Nussbaum's ethical universalist project to Mignolo's decolonial one, cosmopolitan discourses share a global political or ethical perspective, which makes the active revival of cosmopolitanism, as David Harvey notes, "a way of approaching global political-economic, cultural, environmental, and legal questions” (Harvey 2009: 78).

In Episodios cosmopolitas en la cultura argentina, Gonzalo Aguilar distinguishes this critical recuperation of cosmopolitanism from an earlier modernist, mostly aesthetic and intellectual, cosmopolitan discourse at the turn of the twentieth century and its early decades, which participated in the construction of a "modern" national identity and responded to center-periphery relations, but was not primarily concerned with an international political and ethical project, a function left to the discourse of "internationalism" (Aguilar 2009: 28-30). This distinction is important because, while this modernist cosmopolitan discourse has been a central object of study in Latin American, Spanish, and European literary and intellectual studies (Aguilar 2009; Gramuglio 2013; Catelli 2017), the discourse that I address here is mostly an Anglophone theoretical approach whose revival was born with the late twentieth and early twenty-first century expansion of global concerns. Mignolo has called it "critical cosmopolitanism", Harvey "new cosmopolitanism”, Bruce Robbins and Cheah "cosmopolitics”, and Robbins and Paul Lemos Horta, "cosmopolitanisms".

Global concerns have also been at the center of ecocriticism. As the branch of environmental humanities that focuses on the presentation of the environment in literature, ecocriticism addresses the relationship between human beings and their non-human environment. Because it builds on the culture-nature debate, and is increasingly preoccupied with the global environmental crisis, ecocriticism has developed, especially in Scott Slovic and Joni Adamson's third-wave ecocriticism, into a global discourse concerned, in Ursula K. Heise's words, with a "sense of the planet" (Heise 2008).

Arguably, critical cosmopolitanism and ecocriticism have evolved in theoretically similar ways. Especially prolific since the 1990s, both initially tended to conceive their relationship to the globe in terms of aspired harmony. They subsequently progressed toward more skeptical positions at the beginning of the twenty-first century. This evolution toward more problematic forms, and the imbalance between earlier legacies of harmonious relations between human beings and the world and newly problematic ones is the point this essay targets.

Several critics, among whom especially Mignolo, Harvey, Mariano Siskind, as well as Robbins and Horta, trace the evolution of the concept of cosmopolitanism 
from Kant's influential definition - considered the "traditional" or "normative" cosmopolitanism - to the present. As Robbins and Horta brief:

Traditional definitions may tend more to the positive or negative, but they usually agree on some degree of synthesis: cosmopolitanism as a commitment to the good of humans as a whole that overrides all smaller commitments and creates a habitual detachment from the values of the locality. [.. . ] this singular, normative account has been gradually if only partially displaced since the late 1980s by a plural, descriptive understanding. (2017: 2-3)

The initial recuperation of cosmopolitanism emphasized a certain understanding based on common human values with a supranational view.

The pursuit of a harmonious relationship between human beings and nature was also at the core of the ecocritical preoccupations in the 1990s, in what Lawrence Buell calls "first-wave ecocriticism" (2005: 17). As Buell, Heise, and Thornber explain:

First-wave scholarship of the 1990s tended to equate environment with nature; to focus on literary renditions of the natural world in poetry, fiction, and nonfiction as means of evoking and promoting contact with it; to value nature preservation and human attachment to place at a local-communitarian or bioregional level; and to affirm an ecocentric or biocentric ethics, often intensified by some conception of an innate bond - whether biological, psychological, or spiritual - conjoining the individual human being and the natural world. (2011: 419)

Interested in the regional, and with a strong Rousseauian and pastoral legacy, first-wave ecocriticism sought to elucidate and recuperate a certain human, mostly premodern, imagined bond with nature - one that is revisited in some decolonial approaches to environment.

The advent of globalization as a financial and political exploitative endeavor, the growth of neoliberal practices and political ideologies, the impact of postcolonial perspectives, together with a deep environmental crisis spelled out by the material evidence of climate change and damage, and the detection of the Anthropocene have triggered a shift in the objectives and conceptualization of the cosmopolitan and ecocritical approaches at the beginning of the twenty-first century, enforcing much less enthusiastic views on ethico-political relations on a global scale and the biosocial relations of human beings with the environment. Along these lines, new cosmopolitanisms have examined the colonial, religious (Mignolo 2000; 2010) and neoliberal uses and traps of cosmopolitan ideologies (Robbins 2017). These approaches to the right-wing political uses of cosmopolitanism and their alleged intellectual elitism have prompted "cosmopolitan desires" - in Siskind's words - for other kinds of formulations 
that embrace the diversity of human experience in its ethico-political relations to the world. These more positivist approaches claim to have included social scientists, cultural critics and historians in discussions on cosmopolitanism. They newly understand cosmopolitanism as "a characteristic and possession of substantial social collectivities, often nonelite collectivities that had cosmopolitanism thrust upon them by traumatic histories of dislocation and dispossession" (Robbins/Horta 2017: 3), such as colonization, migration, exile, or human trafficking. A wide range of forms has emerged, many included in Robbins and Horta's recent Cosmopolitanisms, among others the cosmopolitanism "of the poor” (Santiago 2004), “decolonial cosmopolitanism” (Mignolo 2000), and "vernacular cosmopolitanism” (Bhabha 1998). As Robbins and Horta highlight, while new cosmopolitanisms seem more apt to explain current global problems and situations, they still struggle with an ethico-political aspiration of improving relations and devising fairer ways of organizing global governance.

Similarly to new cosmopolitanism, as explained by Flys Junquera, Marrero Henríquez, and Julia Barella (2010), Rob Nixon (2015), and Heise, Buell, and Thornber (2011), among many others; by the mid-2000s ecocriticism had turned to considering human damage to the environment and shifted its interest from pristine nature, clearly distinguished from constructed environments to an environment that included the human and the non-human, leaving "nature" as a problematic product of the "environmental imagination" (Buell 1995). Ecocriticism has turned to inequality by intersecting with gender, postcolonial, new historicist and decolonial studies, and tended to examine urban environments, catastrophe and climate change, focusing on pollution, social risk, toxicity, and weighing the damage to the environment produced by human intervention and the massive exploitation of natural resources. In observing those problems in literature locally or regionally and evaluating their impact on a global scale, and strongly affected by the detection of the Anthropocene as a new geological era which registers the human damage to the planet at a biogeological level, second, and especially third-wave ecocriticism have more clearly become a global discourse, concerned with the relations between human beings and the planet at large (Heise 2013; Barbas-Rhoden 2014). In their need to balance traditional forms of environmental imagination and aspirations of the relations between "nature" and "culture", with actual practices and effects in our present historical and geological moment, ecocriticism finds itself in a struggle similar to cosmopolitan discourses.

I propose that Gabi Martínez's Sudd and Joan Benesiu's Gegants de gel display an overlap of the relations which center ecocriticism and cosmopolitanism that reveals the critical maladjustment between ethico-political and environmental aspirations and the conflictive realities they address. 


\section{Gegants de gel, Sudd, and the trouble with environmental and cosmopolitan imagination}

As Jernej Habjan and Fabienne Imlinger (2016) have argued, the novel holds a privileged place in the configuration of global discourses. Siskind distinguishes two ways in which this happens: the first is the "globalization of the novel", where the novel expands into the flag genre of globalization, as he fully shows with several cases, including magic realism as a globalizing literary formula. The second is the novelization of the global, "the production of images of a globalized world as they are constructed in certain novels" (Siskind 2014: 28), to which the ones examined here pertain, given their imagination of globality.

Sudd and Gegants de gel meet the multilingual, multigeographical, and multi-strand developments that characterize a kind of novel that critics like Alexander Beecroft and Héctor Hoyos suggest contributes to the globalization of the genre, its engagement with global concerns in a particular historical system or "ecology" (Beecroft 2015), and the problematization of global discourses themselves such as World Literature (Hoyos 2015; 2017; Siskind 2014). In a way, this loosely-defined global novel not only engages with global tourism, drug trafficking, and the oil extraction business, but it also deploys various discourses of the global, highlighting their limitations. In this sense, for example, Hoyos understands the "global novel" as "a novel that can have a world literary standing” (Hoyos 2015: 6), and one that, in the case of Beecroft and Hoyos's critical work, might be identified in the formal ways in which a worldconsciousness is produced. ${ }^{1}$ Siskind, Beecroft and Hoyos consider World Literature as a critical perspective that participates in global discourses by imagining the "world", or rather "worlds", in narrative. That is, their approach addresses the contextualized, literary poetics that imagines a particular "world" rather than the sociology of the circulation of literature. ${ }^{2}$ In imagining the world, literature is a space that both produces and contests global

1 See Hoyos (2015) and Beecroft's multi-strand "plot of globalization” (Beecroft 2016: 199).

2 While both approaches to World Literature are sometimes perceived as exclusive, as the discussions in the seminar reflected, they also nurture each other, as reflected in Siskind (2014), Sánchez Prado (2018), or Cheah (2016), and in the questions addressed to Benesiu and Martínez's aims in promoting a highly appealing novel to international markets. In the case of Benesiu, it seems to me that the writing of a global novel in a minority language, Catalan, pointed out by Sánchez Prado, finds its reasons not in the counter-writing to global markets but rather in a historical publishing strategy for the building of a Catalan literary tradition that promotes and funds translation to other languages instead of resorting to Spanish as a marketable literary language. 
discourses. I propose to examine Sudd and Gegants de gel from this angle as well. In particular, the novels superpose the formal features of the "wild space" and the "cosmopolitan scene". Patrick Deer's concept of "cosmopolitan scene" refers to a multinational encounter, that appears in fiction through a "scene", understood simultaneously "as a discrete fictional unit”, "the performative and affective sense of 'making a scene,' and the creative and collaborative 'scenes' of music or popular culture" (Deer). The novels' presentation of a "cosmopolitan scene", the imagination of the wilderness, and the uses of narration in that situation will show the inadequacy of ideal relations and highlight the struggles that new cosmopolitanisms and ecocriticism go through in their dealings with the worldly and planetary imagination.

Benesiu's Gegants de gel might be easily considered a global novel for its presentation of multiple characters, stories, places and languages, and the emphasis on mobility and supranational relations. Written by a first-person narrator, this Catalan novel presents a group of characters of varied nationalities sitting around a table at the bar Katowice in Ushuaia to tell the stories that have brought them to seek refuge in the frontier space of Tierra del Fuego.

Escaping from his Spanish family and friends on New Year's Eve and propelled by a painting exhibition, the young narrator decides to visit those "those ice giants, of a white tinged with blue, floating with their majestic, enormous weight on the icy waters of the world-encompassing seas", 3 which for him represented "a primal and ancestral image that I wanted to see"4 (Benesiu 2015: 289). In this escaping trip, he finds himself sitting at a table in the Katowice where "a few characters who seem to come from various places are talking. Their languages mix together. Spanish and English exchange their melodies in no disagreement. Their hands gesticulate the rest of the sentence"5 (Benesiu 2015: 39). The narration emphasizes the distinct national origins and the sharable human experiences composing the cosmopolitan scene and exchange:

There I had them, before me, Guillaume Housseras, the rich Frenchman awaiting the arrival of his girlfriend Anne-Marie; Peter Borum, the Englishman affected by the violent episode involving his son and who had come here to clarify the details of his brother's death; the Mexican Nemesio Coro, representing the escaping spirits of planet Earth; the

3 In the original: "gegants de gel, d'un blanc que girava al blau, surant amb tota la majestat del seu pes enorme sobre les aigües gèlides dels mars dels contorns del món”. All translations of Benesiu and Martínez's novels are my own.

4 Originally, "una imatge primigènia i ancestral que volia veure".

5 Originally, "conversen amb veu audible uns quants personatges que semblen haver arribat de llocs distints. Les llengües es barregen. L'espanyol i l'anglès s'intercanvien la melodia sense entrar en conflicte. Les mans gesticulen la resta de la frase". 
Chilean Martn Medina, genuine commissioner of those abandoned by their family; the hostess Dominka Malczewksa, whose reasons for abandoning Poland probably many years ago to end up owning the Katowice in the distant city of Ushuaia were still a mystery to us. $^{6}$ (Benesiu 2015: 181)

Narrated in sequence, the characters' individual stories mostly reveal an escape from localized violence. The Englishman Peter Borum travels to the Tierra del Fuego to unravel the mysterious death of his brother, a former soldier in the Malvinas' war who appeared dead near Lago Escondido and whose death the Argentinean authorities quickly declared as a suicide and did not investigate any further. Borum escapes from the torment of having his son jailed for murdering an individual who had abused him cybernetically. The Mexican Nemesio Coro escaped from a prosecution resulting from his brother's debts and involvement in drug trafficking. The Chilean Martín Medina was a victim of the Pinochet dictatorship, and the bar owner Dominka Malczewska had survived the Russian Katyn massacre during World War II. These localized violent stories underline their national associations (Chilean Pinochet dictatorship, and Mexican narcotrafficking, for example), while simultaneously displaying an involvement (cyber abuse and drug war, World War II) that transcends historical and current national borders. Furthermore, the violent stories signal conflicts that have paradigmatically raised cosmopolitan sympathy, not least because of their media popularity, even topicality, which the narrator also remarks on. Because of their simultaneous localization and familiarity on a global scale, and their violence, the stories are highly sharable.

The narrator suggests the catalyzing effect of the cosmopolitan scene, when stating that those people "have come to the Katowice to meet and tell each other the individual reasons that brought them to this vital frontier that Ushuaia is. Dominika's bar has acted as catalyst for convergent forces on a frozen night in one of the world's extremes"' (Benesiu 2015: 42). Through this and other similar comments, the narrator willingly interprets the cosmopolitan

6 Originally, "Allà els tenia, davant meu, Guillaume Housseras, el francès ric que esperava l'arribada de la seua nòvia Anne-Marie; Peter Borum, l'anglès afectat per l'episodi violent protagonitzat pel seu fill i que havia arribat per esclarir la mort del seu germà; el mexicà Nemesio Coro, representant dels esperits en estat de fugida del planeta Terra; el xilè Martn Medina, genuí comissionat dels individus abandonats per la família; l'amfitriona Dominika Malczewska, de qui encara no sabíem els motius que l'havien duta a abandonar Polònia segurament feia molts anys i acabar regentant el Katowice a la llunyana ciutat d'Ushuaia”.

7 Originally, "han vingut al Katowice per trobar-se i contar-se així els motius particulars que els han dut fins a aquesta frontera vital que és Ushuaia. El bar de Dominika ha actuat com a catalitzador d'unes forces convergents en la nit gelada d'un dels extrems del món”. 
situation through the idea of human solidarity that prompts confession and mutual understanding of the violent stories that brought the characters to the scene, and resorts to the ethical imagination of a cosmopolitan harmony generated in company and sympathy for personal suffering in a wide multinational world.

A related situation occurs on board La Nave, the ship traveling through the vast Sudd swamp to reach a southern city carrying a multinational group of people on a mission to negotiate the rebuilding of the "City" after a Sudanese war. The passengers include a select group of local tribal leaders, a prominent and cruel Sudanese war soldier and his sick wife, a Canadian photographer, a French biologist, an English oil company businessman, five Chinese realestate businessmen, a local minister, the captain and his daughter, and a Spanish and a Chinese translator, who learn each other's stories and face the challenging situation of being attacked and becoming stranded in the middle of a 57,000 square-kilometer natural space. The group has been carefully selected to discuss and reach an agreement that would implement the peace treaty and design the plan for the aftermath of the war, on the basis of individual local roles, abilities, and power. The multinational expedition seeks to resolve a conflict through international cooperation and agreement, based on their confidence in cosmopolitan discourses of mediating political conflicts at a supranational level.

Moreover, Sudd also discloses the ethical possibilities of a cosmopolitan group in the newly organized "city" (Martinez 2007: 229) that the ship becomes, since the characters similarly confess their stories. For example, the Chinese translator Han Tsu confesses to the narrator that he is becoming deaf in one ear, while the ferocious warrior Wad tells him that he does not want to kill anyone else. As the narrator remarks, "even the great hermits sometimes need somebody to tell their truths and, after all, I was only a white foreigner who would one day vanish with a handful of African stories"8 (Martinez 2007: 251). Despite the wishful assumptions and expectations, these harmonious ethico-political situations would be deeply affected by the environment where they take place, which initially seems to facilitate the global human sense of communion just shown.

The imagination of the wilderness enormously helps the sense of human communion with the planet, and that human beings are part of an all-powerful nature. Both settings in the novel are partially read through the imagination of

8 Originally, "[i]ncluso los grandes ermitaños necesitan una vez interlocutores a los que explicar su verdad y yo, después de todo, no era más que un blanco extranjero que un día se esfumaría con un puñado de historias de África”. 
the wilderness; an imagination that is, especially in Gegants de gel, strongly criticized. Benesiu's novel plays with Tierra del Fuego as "the last territory of territories [.. .] in the middle of the night on a rotating planet" (Benesiu 2015: 41). The narrator suggests that it is

one of the least common places on the planet. A place deliberately sought out to avoid the multitudes and to experience the frontier feeling. The territory where humanity borders on nature at one of its extremes is called Ushuaia and it is found at a 540 South latitude. It's motto reads: "Ushuaia, the end of the world, the beginning of everything". ${ }^{10}$ (Benesiu 2015: 22)

At the end of the novel, the sense of an isolated frozen territory where incidents occur and are left unknown reinforces the imagination of the wilderness.

Wilderness plays a stronger role in Sudd, where the passengers of La Nave face the overwhelming isolation, vastness and unpredictable dynamics of the open natural space of the Sudd swamp. The ship becomes trapped in the middle of moving bushy islands and floating vegetation that constantly reconfigure the landscape and hinder navigation, shaping a chaotic, ageless natural space:

From the watchtower I saw the chaos. An uncertain world. [...]

They say that the Sudd was formed in some inmemorial millenium from the lack of shores. The river burst its banks and spread out over the plain and the result of that flooding was the universe of lakes and sinuous channels determined by the floating islands which, by naturally varying their position, turned the swamp into a mobile labyrinth.

The Sudd is as large as many medium-sized European countries, with the difference that it constitutes a limitless kingdom of shifting confines. Geographers cannot determine its frontiers and when they do, they soon have to modify them. ${ }^{11}$ (Martínez 2007: 56)

9 Originally, "últim territori dels territoris [. . . al bell mig de la nit d'un planeta que gira”. 10 Originally, "un dels llocs menys comuns del planeta. Un lloc buscat a consciència per evitar les multituds i per poder provar la sensació de frontera. El territori on la humanitat limita amb la naturalesa per un dels extrems es diu Ushuaia i els troba a 54을 de latitud sud. La seua llegenda diu: 'Ushuaia, fin del mundo, principio de todo'”.

11 Originally, "Desde la atalaya vi el caos. Un mundo incierto. [. . . ]

Dicen que el Sudd se formó en algún milenio inmemorial a causa de la falta de orillas. El caudal madre del río se expandió por la llanura y el resultado de la inundación era aquel universo de lagos y canales sinuosos determinados por las islas flotantes que, al variar naturalmente su posición, convertían el pantano en un laberinto móvil.

El Sudd es tan grande como numerosos países europeos de tamaño medio, con la distinción de construir un reino sin límites, de confines corredizos. Los geógrafos no pueden especificar fronteras y cuando lo hacen deben modificarlas al poco". 
In agreement with the imagination of the wilderness, this is "a world from another era. Preevolutionary"12 (Martínez 2007: 105), where time is suspended in such a way that human beings are driven to ask themselves: "To what age had that place returned us to?", "What did the future mean there"? ${ }^{13}$ (Martínez 2007: 200, 201). The vastness of the place is felt as "abrumadora" ('overwhelming') (Martínez 2007: 130), given its unexpected power over the ship and its passengers, and it finally surrounds and imprisons the ship in an enclosed vegetal, watery spot from which it cannot move. Under those circumstances, "all of a sudden, the animosity of outside commandos and even the burning threats in La Nave seemed to pale in comparison to the unfathomable vastness of our well-defined opponent" ${ }^{14}$ (Martínez 2007: 297). This quest for survival sets the familiar opposition between human beings as a group-species against the opponent "nature", to be found in the fantasy of natural wilderness.

The situation of a cosmopolitan scene in these wild spaces, however, is less ideal than it may seem at first sight. It turns out to be an especially conflictive conjunction. In many ways the landscapes of Tierra del Fuego and Sudd are presented as Deleuzian "smooth spaces", those fluid spaces whose physical features make them resistant to possession, spaces opposed to settlement because they have no paths, metric divisions or channels, but are only marked by traces that are erased and move in their trajectory (Deleuze/Guattari 1980: 472). The intrinsic ambiguity of smooth spaces suggests that these imagined wild spaces are also inherently problematic. The novels portray them as hosting stories of uncertain development and conflictive discourse. The narrative situations in the wilderness not only produce tales of cosmopolitan harmony but also engender conflictive relations through narrative unreliability and invented stories.

Indeed, the cosmopolitan table in Gegants de gel that seems to invite a special communion turns out to be an optimum setting for conflict. On hearing the other characters' stories, the narrator feels his own is not as dramatically interesting, so he considers the possibility of "inventing something, of taking the liberty of employing a poetic lie so to keep myself alive in that table of night-time confessions"15 (Benesiu 2015: 125). In a similar line to the one expressed in Sudd,

12 Originally, "un mundo de otra era. Preevolutivo".

13 Originally, “¿A qué edad nos había devuelto aquel lugar?”, “¿Qué significaba allí el futuro"?

14 Originally, "la inquina de comandos exteriores e incluso las amenazas que bullían en $L a$ Nave resultaban de repente casi burdas ante la inaprensible envergadura de nuestro ya bien definido rival".

15 Originally, “inventar alguna cosa, de prendre'm la llicència de fer servir una mentida poètica per a mantenir-me viu en aquella taula de confessions nocturnes”. 
anonymity in no-man's land actually attracts a special kind of confessional, untested narration, as the narrator suggests: "the magnetism irradiated by another human being who listens to you and who you would never cross paths with again enables confidences to be shared"16 (Benesiu 2015: 126). While waiting for his turn at storytelling, the narrator realizes that Martin Medina is telling the story of Daniel Rojas that he also wanted to tell pretending it was his own, so he turns to French cinema and his own experience for inspiration to improvise an engaging story. The following day, as the narrator and Peter Borum are walking in search of some traces lost in the snow twenty years ago in an attempt to understand the mysterious unresolved death of the latter's brother, they find Nemesio Coro's fresh corpse, just after his murder. All signs point to Martín Medina as the murderer, but he has fled the country and the crime is never fully asserted as resolved in the novel. The narrator reflects on Medina's stolen story in the cosmopolitan scene:

Now it turned out that perhaps everything Medina had said was false, and that the time he spent sitting among us at the table only served him to observe his victim carefully, with the patience of trained and determined murderers [.. . ] Nemesio had trusted us with his story of a Mexican fugitive with a confidence that seemed excessive to all of us. ${ }^{17}$ (Benesiu 2015: 228)

While the text keeps the narration close to the narrator, and therefore makes his presence at the crime scene and his early accusations at the Argentinean police detention center convincingly false, the parallelisms between fictional invention and criminal lies in a cosmopolitan narrative framework where there are no tools for judgment because there are no references through which fabrication might be detected, suggest that the narrator's allegedly innocent use of poetic license has been playing with the same dangerous possibilities of Medina's narrative. In that sense, in highlighting the uses of narration for actual crime, the novel also reflects back on its narrator and the potential conflicts produced by unreliable narration both with regards to the story being told and to the global readers who might also be easily deceived.

16 Originally, “el magnetisme que irradia un altre ésser humà que t'escolta i amb qui mai no et tornaràs a creuar en la teua vida permet el subministrament de les confidències".

17 Originally, "Ara resultava que potser tot el que Medina havia dit era fals i que el temps que va passar assegut a la taula entre nosaltres sols li va servir per a observar detingudament la seua víctima, amb la paciència dels assassins ensinistrats i sorruts [...] Nemesio ens havia confiat la seva història de mexicà fugitiu amb una confiança que a tothom ens va semblar excessiva”. 
In Gegants de gel the questioning of the natural wilderness contributes to highlighting this misleading imagination of space - a kind of "geografía espiritual" ('spiritual geography') (Ferrer 2004: 54) - and warns of the risk of not apprehending its socioeconomic and political dimensions. In a similar narrative resource to the use of stories that come from other characters and films, the narrator's imagination of the wilderness is significantly taken from mediating representations, through photographs (from various sources, included in the novel: a map, characters, landscape close-ups), movies (especially Lisandro Alonso's Liverpool), paintings (photographs of Frederic Edwin Church's iceberg paintings), and literature (notably W.G. Sebald, Roberto Bolaño, Stanisław Lem) that contribute to the dislocation between the environmental imagination of the wilderness and the actual tourism, industrialization, and penal institutions that are part of the historical reality of Ushuaia and Tierra del Fuego. ${ }^{18}$ In the literary tradition of the English travelers in Argentina that Adolfo Prieto documents, creators of the imagination of Tierra del Fuego and Patagonia as part of a massive European (and now global) search for "autenticitats arreu del món" ('authenticities around the world') cannot disguise, as the narrator admits, that travelers are "presoners de la nostra pròpia comèdia" ('prisoners of our own performance') (Benesiu 2015: 145), complicit in touristic propaganda, and instrumental users of it. In this sense, ruptured environmental desires are self-consciously surrounded by socioeconomic structures and practices that contradict their fabricated images and therefore disrupt the separation between nature and culture that would postulate the wilderness as the last refuge from human damage, intervention, and political violence. This postulation not only does not prevent conflict but, as the examples provided show, even stimulates it. ${ }^{19}$

In Sudd the peculiar dynamics of the swamp determine the conflicts that arise in the narrative. The Spanish translator instigates a misunderstanding that produces the novel's central conflict. In this truly cosmopolitan scene, the starving passengers have just learnt about the food restrictions that the crew has decided for the poorest groups in view of the uncertain duration of the vegetal siege in which La Nave is trapped. At this moment, the narrator tells

18 As Nora Catelli recalled and Gegants de gel explicitly refers to, Ushuaia was one of the great penitentiary centers in Argentina, contradicting a wild Tierra del Fuego.

19 This point prompted an interesting discussion in the seminar centered on the imagery of Patagonia and Tierra del Fuego in Argentinean literature, for which Jorge Locane suggested Christian Ferrer's essays (2004) on the imagination of Patagonia, and Locane and Catelli recommended Prieto's monograph (1996). Alejandra Uslenghi, Alejandra Laera, Alexandra Ortiz Wallner, and Héctor Hoyos helpfully interrogated the pictures' effects in that imagination. 
a Chinese outcast to act furiously against this food limitation, and deceiving him through mistranslation, makes him announce that minister Osman is the leader of this rebellion against Gao's and Norton's food rationing policy and that the desperate passengers in the "Inferior Level" should support it, tear open the sorghum sacks, and eat their fill. Taking advantage of the fact that he and Hang Tsu are the only ones who know Arabic, English, Spanish, and Chinese, the narrator produces the conflict by mistranslating, thereby inventing the words that he pretends to be literally translating. This creates a dangerous division among the crew, and empowers the translator with the "imperium" that the section bears as a title. The narrator states with satisfaction:

That was how the people started to eat their defenses while venerating the man who had cast them into hell.

Thanks to me.

I modified the feelings of the mob, pointing to the leader I was most interested in raising up.

Using only my words.

I felt big, I certainly did.

I had La Nave in my hands.

In my tongue. ${ }^{20}$ (Martínez 2007: 225)

It is through language and taking advantage of the interstitial space between languages and cultures that the narrator can feel the "omnipotente gobernador del caos. Gobernador del Sudd" ('omnipotent governor of chaos. Governor of the Sudd') (Martínez 2007: 265). While blackmail is one of the outcomes of this conflict, the final objective of his new power remains unclear. However, what is ironically clear is that the vastness and openness of the territory offers him the possibility of gaining this imperium, "in the void. That is what is most curious. I was sovereign in the middle of the most terrifying void ever known, where not even the land is firm"21 (Martínez 2007: 267).

20 Originally, "Así fue como la gente comenzó a comerse las defensas venerando al hombre que les había abocado al infierno.

Gracias a mí.

Modifiqué el sentir de la turba, señalándole al líder que en ese momento más me importaba aupar.

Sólo a base de palabras.

Me sentí grande, ya lo creo.

Tenía a La Nave en mis manos.

En mi lengua".

21 Originally, "En la nada. Eso es lo más curioso. Fui soberano en mitad de la más estremecedora nada conocida, donde ni siquiera la tierra es firme”. 
In this episode, the narrator reveals himself as the deceitful translator that the other characters have been suggesting when mistrusting his translations. Osman tells him: "Nobody trusts you here. You don't speak our language well, you make mistakes with words, you have a strange accent and, as you know, people distrust those who do not speak like them"22 (Martínez 2007: 325). The mentioned episode acts as a turning point in the novel in revealing that the mistrust the narrator protests against by initially suggesting that his translations tend to make the exchanges smoother and avoid insulting language or cultural misunderstanding might be justified because he literally lies, generates conflict, and uses discourse as a weapon for gaining personal power and subjecting others to their inability to discuss anything without mediation. This shows the first-person homodiegetic narrator as an unreliable narrator that automatically suspends the story he has told in uncertainty. By not translating to Spanish many of the Chinese sentences, and manipulating discourse, Sudd suggests a gap that hosts a potential unreliability and the enormous possibilities of misreading the novel, similar to the effects that the narrative voice in Gegants de gel produces.

The liminal, smooth space where these characters meet strongly invites the division between nature and culture, which places the individual in front of the wilderness' unreachability and unfathomability, where human relations blur in the homogeneity of the species-group that inhabits the planet. While these novels emphatically display the imagined wilderness in their characters' perception of their surroundings as outside social and political constraints, Tierra del Fuego and the Sudd swamp ultimately reveal themselves not as the expected spaces of harmony but as spaces that enable and legitimize invented tales, misunderstood personalities, and manipulation of narratives that lead to fierce confrontation and unresolved crimes. In other words, it is precisely in those spaces in which the political and national ties can be released in a communion of storytelling or in the common struggle against nature, where violent conflict has, paradoxically, a wider ground in which to appear.

22 Originally, "aquí nadie se fía de usted. No habla bien nuestra lengua, se equivoca en palabras, tiene un acento raro y, en fin, ya se sabe que la gente desconfía de los que no hablan como ellos". 


\section{The imagination of the wilderness, the cosmopolitan scene, and their challenges to world literature: A critical dislocation}

Gegants de gel and Sudd suggest that the transnational global understanding that cosmopolitanism aspired to is a desire that, when set in a place imagined as outside the social and the political (a natural, wild, common space), reveals itself as problematic and potentially more conflictive than expected. The overlap of cosmopolitan scenes in wild spaces in fact questions whether cosmopolitanism can be thought of outside political affiliations, since the locations of Tierra del Fuego and Sudd conceived as wild and outside social and political regulations, in fact lead us to reread political relations problematically (for example, by inventing stories and rearranging alliances) between characters with an ultimately unavoidable national adscription or geopolitical determination (Polish, Chinese, European, Sudanese), triggering ethical and political relations that are even more perverse because they have larger room for action. The "wilderness" is conceived under those circumstances as a political and ethical "empty" space, a smooth space whose fluidity and difficult traceability makes it permissive, and where political and ethical relations cannot only not be fixed, but, like the loosely oriented power of Sudd's narrator, are also volatile and at times arbitrary.

Similarly, the cosmopolitan scenes in an open, wild space disorient the human unitary, species-driven response that ecocriticism adopts in its relation to the environment. The human ideal that makes the species recognize itself as such when contemplating (as in Gegants de gel) or confronting (as in Sudd) the natural, wild spaces of Tierra del Fuego and Sudd, is destabilized by the fact that its relationship with nature necessarily implies the ethical and political relations between individuals. As the novels suggest, the imagination of the wilderness cannot be disentangled from the political and ethical function of space. That is, Gegants de gel and Sudd illustrate the limitations of thinking only of how the human species as a uniform group relates to the wild, depoliticized spaces, forcing the readers to consider the ways in which political relations distort the apparently neat nature-culture dynamics.

From this point of view, in their interaction, the global perspectives of cosmopolitanism and ecocriticism dislocate each other. Situated in what might appear as ideal global conditions - a multinational group with a transnational aim in a wild, unconditioned space - the novels reveal the weaknesses that harmonious, dialectical discourses entail, showing a lack of fluidity in those situations, which, contrary to the initial harmonious expectations the narrative situations generate, quickly reconfigure in the most perverse ways, creating fertile ground for 
misunderstanding, manipulation, lies, and crime. Precisely, the use of personal narratives in a context with an extended margin for action, leads us to reflect on how the interaction of various global discourses affects the relations with which each of them is concerned (individuals in their ethical and political relations in cosmopolitan discourses; the human species and environment in ecocriticism), thereby illuminating their most contradictory and least amiable effects. In reflecting the problematic harmonious ideal of traditional cosmopolitanism and the trouble with wilderness (Cronon 2015; Mellor 2014), the novels embody the move towards critical cosmopolitanism and to second and third-wave ecocriticism. But they go even further. In anchoring the conflict at the intersection between the cosmopolitan and the environmental imagination, the novels index the limitations of global discourses focusing on the biological or the ethico-political relations with the planet and the world exclusively, and illuminate the challenges of thinking about them together.

Paradoxically, global novels like Gegants de gel or Sudd invite criticism to reconsider those allegedly untouched spaces as fitting for the ecocritical and cosmopolitan perspectives. These novels participate in the current revisions of the cosmopolitan and ecocritical discourses mentioned above. Being global in their focus and their approach, the novels disclose the paradoxes and contradictions of those critical discourses and their difficult intersections. This suggests that world literature approaches might be more productive in exploring the uses of global discourses in literature than in pursuing any global cosmopolitan ideal. This approach would help us better understand the imagination of the world and the planet in its varied forms that today guide the literary and critical narratives and discourses, and the practices that we perceive as global.

\section{Works cited}

Adamson, Joni (2010): “Environmental Justice and Third Wave Ecocritical Approaches to Literature and Film”. In: Ecozon@, 1, 1, pp.11-16.

Aguilar, Gonzalo (2009): Episodios cosmopolitas en la cultura argentina. Buenos Aires: Santiago Arcos Editor.

Barbas-Rhoden, Laura (2014): "Hacia una ecocrítica transnacional: Aportes de la filosofía y crítica cultural latinoamericanas a la práctica ecocrítica”. In: Revista de Crítica Literaria Latinoamericana, 40, 79, pp. 79-96.

Beecroft, Alexander (2016): “On the Tropes of Literary Ecology: The Plot of Globalization”. In: Habjan, Jernej/Imlinger, Fabienne (eds.): Globalizing Literary Genres: Literature, History, Modernity. New York: Routledge, pp. 195-212.

Beecroft, Alexander (2015): An Ecology of World Literature: From Antiquity to the Present Day. Brooklyn, NY: Verso. 
Benesiu, Joan (2015): Gegants de gel. Barcelona: Edicions del Periscopi.

Bhabha, Homi K. (1998): "Spectral Sovereignty, Vernacular Cosmopolitans, and Cosmopolitan Memories”. In: Robbins, Bruce/Horta, Paulo Lemos (eds.): Cosmopolitanisms. New York: New York Press, pp. 141-152.

Buell, Lawrence (2005): The Future of Environmental Criticism: Environmental Crisis and Literary Imagination. Malden, MA: Blackwell.

Buell, Lawrence (1995): The Environmental Imagination: Thoreau, Nature Writing, and the Formation of American Culture. Cambridge, MA: Belknap Press of Harvard University Press.

Buell, Lawrence/Heise, Ursula K./Thornber, Karen (2011): “Literature and Environment”. In: Annual Review of Environment and Resources, 36, 1, pp. 417-440.

Catelli, Nora (2017): “Asymmetry: Specters of Comparativism and the Circulation of Theory". In: Journal of World Literature, 2, 1, pp. 11-26.

Cheah, Pheng (2016): What Is a World?: On Postcolonial Literature as World Literature. Durham: Duke University Press.

Cheah, Pheng (2006): “Cosmopolitanism”. In: Theory, Culture \& Society, 23, 2-3, pp. 486-496.

Cheah, Pheng/Robbins, Bruce (eds.) (1998): Cosmopolitics: Thinking and Feeling Beyond the Nation. Minneapolis: University of Minnesota Press.

Cronon, William (2015): “The Trouble with Wilderness; or, Getting Back to the Wrong Nature". In: Hiltner, Ken (ed.): Ecocriticism: The Essential Reader. London/New York: Routledge, pp. 102-119.

Deer, Patrick (2018): “British Cosmopolitanism after 1980”. In: Boxall, Peter (ed.): The Cambridge Companion to British Fiction Since 1980. Cambridge/New York: Cambridge University Press. Manuscript courtesy of the author.

Deleuze, Gilles/Guattari, Félix (1980): Capitalisme et schizophrénie: Mille plateaux. Paris: Éditions de Minuit.

Ferrer, Christian (2004): Cabezas de tormenta: Ensayos sobre lo ingobernable. Buenos Aires: Anarres.

Flys Junquera, Carmen/Marrero Henríquez, José Manuel/Barella, Julia (eds.) (2010): Ecocríticas: Literatura y medio ambiente. Madrid/Frankfurt: Iberoamericana/Vervuert.

Gramuglio, María Teresa (2013): Nacionalismo y cosmopolitismo en la literatura argentina. Rosario: Editorial Municipal de Rosario.

Habjan, Jernej/Imlinger, Fabienne (eds.) (2016): Globalizing Literary Genres: Literature, History, Modernity. New York/London: Routledge.

Harvey, David (2009): Cosmopolitanism and the Geographies of Freedom. New York: Columbia University Press.

Heise, Ursula K. (2013): “Globality, Difference, and the International Turn in Ecocriticism”. In: PMLA, 128, 3, pp. 636-643.

Heise, Ursula K. (2008): Sense of Place and Sense of Planet: The Environmental Imagination of the Global. Oxford: Oxford University Press.

Hoyos, Héctor (2017): "Corpse Narratives and the Teleology of World Literary History". In: Journal of World Literature, 2, 1, pp. 63-79.

Hoyos, Héctor (2015): Beyond Bolaño: The Global Latin American Novel. New York: Columbia University Press.

Martínez, Gabi (2007): Sudd. Madrid: Alfaguara. 
Mellor, Leo (2014): “The Lure of Wilderness”. In: Westling, Louise (ed.): The Cambridge Companion to Literature and the Environment. Cambridge/New York: Cambridge University Press, pp. 104-118.

Mignolo, Walter D. (2010): “Cosmopolitanism and the De-Colonial Option”. In: Studies in Philosophy and Education, 29, 2, pp. 111-127.

Mignolo, Walter D. (2000): "The Many Faces of Cosmo-Polis: Border Thinking and Critical Cosmopolitanism”. In: Public Culture, 12, 3, pp. 721-748.

Müller, Gesine/Locane, Jorge J./Loy, Benjamin (2018): Re-mapping World Literature: Writing, Book Markets and Epistemologies between Latin America and the Global South / Escrituras, mercados y epistemologías entre América Latina y el Sur Global. Berlin: De Gruyter.

Nixon, Rob (2015): “Environmentalism and Postcolonialism”. In: Hiltner, Ken (ed.): Ecocriticism: The Essential Reader. London/New York: Routledge, pp. 197-210.

Prieto, Adolfo (1996): Los viajeros ingleses y la emergencia de la literatura argentina, 1820-1850. Buenos Aires: Editorial Sudamericana.

Robbins, Bruce (2017): The Beneficiary. Durham: Duke University Press.

Robbins, Bruce/Horta, Paulo Lemos (eds.) (2017): Cosmopolitanisms. New York: New York University Press.

Sánchez Prado, Ignacio M. (2018): “África en la imaginación literaria mexicana.

Exotismo, desconexión y los límites materiales de la “epistemología del sur”. In: Müller, Gesine/Locane, Jorge J./Loy, Benjamin (eds.): Re-mapping World Literature. Berlin: De Gruyter, pp. 61-79.

Santiago, Silviano (2004): O cosmopolitismo do pobre: Crítica literária e crítica cultural. Belo Horizonte: Editora UFMG.

Siskind, Mariano (2014): Cosmopolitan Desires: Global Modernity and World Literature in Latin America. Evanston: Northwestern University Press.

Slovic, Scott (2010): “The Third Wave of Ecocriticism: North American Reflections on the Current Phase of the Discipline”. In: Ecozon@, 1, 1, pp.1-10. 
